\title{
Trace and Toxic Elements Accumulation in Food Chain Representatives at Livingston Island (Antarctica)
}

\author{
R. Metcheva (Corresponding autor) \\ Institute of Zoology, Bulg. Acad. of Sciences \\ bld. Tzar Osvoboditel 1, 1000 Sofia, Bulgaria
}

Tel: 359-2988-5115 E-mail: rummech@yahoo.com

L.Yurukova

Institute of Botany, Bulg. Acad. of Sciences

Acad. G. Bonchev Str., Bl. 23, 1113 Sofia, Bulgaria

Tel: 359-2979-3765 E-mail: yur7lild@bio.bas.bg

\section{Bezrukov}

Taras Shevtchenko National University of Kyiv - Kyiv, Ukraine

Tel: 380-44-522-3995Ｅ-mail: bezrukov@gmail.com

\section{Beltcheva}

Institute of Zoology, Bulg. Acad. of Sciences

bld. Tzar Osvoboditel 1, 1000 Sofia, Bulgaria

Tel: 359-2988-5115 E-mail: mnedialkova@gmail.com

Y. Yankov

Bulgarian Antarctic Institute, bld. Tzar Osvoboditel 15

1000 Sofia, Bulgaria

Tel: 359-2876-0426Ｅ-mail: lz2uu@vip.bg

\section{K. Dimitrov}

Institute of Zoology, Bulg. Acad. of Sciences,

bld. Tzar Osvoboditel 1, 1000 Sofia, Bulgaria

Tel: 359-2988-5115 E-mail: krastiodimitrov@gmail.com

The research is financed by Grant B 16-15/2006 from the Bulg. Nat. Sci. Fund

\begin{abstract}
First data for concentrations and distribution of trace and toxic elements in tissues and organs of brown skua (Catharacta lonnbergi), Gentoo penguin (Pygoscelis papua), crabeater seal (Lobodon carcinophagus), notothenioid fish (Notothenia coriiceps) and in krill (Euphausia superba), collected on Livingston Island (South Shetlands), Antarctica are presented. Lead, cadmium, copper, zinc, manganese and cobalt were studied in liver, kidney, bone, spleen, muscle, heart and feathers. Generally, higher concentrations of toxic elements were found in liver and kidneys than in other investigated tissues. The same elements in krill and notothenioid fish were also determined. The obtained data could
\end{abstract}


serve as a starting point for broader investigation of the possible changes in the ecosystem of Antarctic Peninsula under climate and environmental changes.

Keywords: Heavy metals, Brown skua, Gentoo penguins, Crabeater seal, Notothenioid fish, Krill

\section{Introduction}

For the study of toxic elements concentrations in predators' fauna Antarctica is an area of special interest. It was believed that such remote environment was practically unpolluted. Recently however anthropogenic source seems to be an explanation for a significant excess of lead and zinc concentrations in the environment (Dick, 1991). Along with this, heavy metals may be high in Antarctic wildlife, which is also the case for the increasing quantity of cadmium (Honda et al., 1986; Szefer et al., 1994). Upwelling of natural cadmium rich deep water (Holm-Hansen, 1985) might be the source for elevated cadmium loads in krill (Euphausia superba) (Petri and Zauke, 1993). It is the main food source for most Antarctic marine predators and is present all year round in marine surface layers (Smith et al. 1995). It composes a substantial part of the diet of notothenioid fish (Notothenia coriiceps) (Barrera-Oro, 2003), crabeater seals (Lobodon carcinophagus) (Siniff, 1991) and Gentoo penguins (Pygoscelis papua ellsworthi) (Volkmann et al., 1980). Brown skua (Catharacta lonnbergi) feedings on penguin eggs, chicks, krill, fish and scavenge (Smith et al., 1995) represents as one of the top predators of an Antarctic food web. All these species are excellent subjects for examination of heavy metals presence because they are long living, feed at different distances from land and exhibit different trophic levels (Smith et al., 1995; Trivelpiece and Trivelpiece, 1990; Walsh, 1990).

Since all Antarctic species are protected under the Antarctic treaty (from 1959) there is impossible to collect animals tissues and organs for analyzes. Because of that in any case when is possible it is convenient to collect biological materials from the dead animals. This way becomes a chance to provide additional to the existing scare literature data.

Several studies report metal concentrations in the predators' tissues of various Antarctic areas. However no enough data for a set of representatives from different levels of the relatively short trophic chain from many areas are available to date. The objective of the study is to gather baseline information for trace metals lead, cadmium, copper, zinc, manganese and cobalt in Antarctic Ocean biota from Livingston Island. It may be needed to detect, measure and monitor future environmental changes and aimed at contributing on potential pollutants of ecotoxicological interest in the Antarctic ecosystem.

\section{Material and Methods}

The present material consisted of different Antarctic animals, mainly top predators collected during three Antarctic summer seasons $(2002 / 3,2003 / 4,2005 / 6)$ at South Bay, Livingston Island $\left(62^{\circ} 38^{\prime 2} 29^{\prime \prime}\right.$ S and $60^{\circ} 24^{\prime} 53^{\prime \prime}$ W), South Shetlands. The island lies in the zone of oceanic Antarctic climate.

Along with the fresh dead specimens, an opportunistic approach in collecting sample material was used. Only one brown skua (Catharacta lonnbergi), crab eater seal (Lobodon carcinophagus) and Gentoo penguin (Pygoscelis papua ellsworthi) were collected. The notothenioid fish (Notothenia coriiceps) $(\mathrm{n}=3)$ and krill (Euphausia superba) $(\mathrm{n}=19)$ were collected deliberately by fishing and using a zooplanctonic net.

Tissue concentrations of trace elements ( $\mathrm{Pb}, \mathrm{Cd}, \mathrm{Cu}, \mathrm{Zn}, \mathrm{Mn}$ and $\mathrm{Co}$ ) were determined in liver, kidneys, spleen, bones, muscle, heart, feathers in adult individuals of brown skua, Gentoo penguin and crab eater seal. The same elements in the whole body of krill and notothenioid fish were determined.

All the collected samples were dried at $60{ }^{\circ} \mathrm{C}$ until constant weight and wet mineralized. About 1-1.5 g of the dried material was treated with $15 \mathrm{ml}$ nitric acid $(9.67 \mathrm{M})$ overnight. The procedure was continued with heating in a water bath, followed by addition of $2 \mathrm{ml}$ hydrogen peroxide. This treatment was repeated until full digestion. The filtrate was diluted with double distilled water up to $25 \mathrm{ml}$. All solutions were stored in plastic flasks. Duplicates of each sample were prepared independently. The elements $(\mathrm{Mn}, \mathrm{Zn}, \mathrm{Cu}, \mathrm{Pb}, \mathrm{Cd}$ and $\mathrm{Co}$ ) were determined by atomic emission spectrometry (AES) with inductively coupled plasma (ICP). VARIAN VISTA-PRO instrument was used. The detection limits in the samples analyzed were: $0.004 \mathrm{mg} / \mathrm{l}$ for $\mathrm{Zn}, \mathrm{Cu}, \mathrm{Cd}$ and $\mathrm{Co}, 0.002 \mathrm{mg} / \mathrm{l}$ for $\mathrm{Mn}$, and $0.03 \mathrm{mg} / \mathrm{l}$ for Pb. The analytical precision was secured by replicating (deviation between the duplicates was below $5 \%$ in all cases) and by use of blanks and stock standard solutions $(1000 \mu \mathrm{g} / \mathrm{ml}$ Merck) for the preparation of working aqueous solutions. The mean analytical errors of the various samples (3 measurements for each solution) were higher for $\mathrm{Pb}(40.0 \%), \mathrm{Co}(30.6 \%), \mathrm{Cd}$ (23.6\%), followed by $\mathrm{Mn}(9.0 \%), \mathrm{Cu}(5.0 \%)$ and $\mathrm{Zn}(1.0 \%)$. Quality control was checked by standard reference materials (CRM 281 and CRM 142R). The concentrations were expressed as $\mathrm{mg} / \mathrm{kg}$ dry weight.

\section{Results and Discussion}

\subsection{Antarctic krill (Euphausia superba)}

Mean concentrations of $\mathrm{Pb}(0.40 \pm 0.18 \mathrm{mg} / \mathrm{kg}), \mathrm{Cd}(0.60 \pm 0.14 \mathrm{mg} / \mathrm{kg}), \mathrm{Cu}(42.8 \pm 0.33 \mathrm{mg} / \mathrm{kg}), \mathrm{Zn}(50.0 \pm 0.49$ $\mathrm{mg} / \mathrm{kg}), \mathrm{Mn}(14.0 \pm 0.14 \mathrm{mg} / \mathrm{kg})$ and Co $(0.40 \pm 0.12 \mathrm{mg} / \mathrm{kg})$ in krill sampled at Livingston Island (Table 1) were comparable to the values for $\mathrm{Pb}, \mathrm{Cd}, \mathrm{Cu}, \mathrm{Zn}$ and $\mathrm{Mn}$ obtained from East Antarctica. Karasawa and Mishima (1981), 
Honda et al. (1987), Yamamoto et al. (1996). Stoeppler and Brandt (1979) and Soszka et al. (1981), who examined some trace elements in the Antarctic krill in the areas of Scotia Sea, Bellingshausen Sea and the Weddell Sea, found comparable levels. Locarnini and Presley (1995) obtained similar values along the Antarctic Peninsula. The relatively high concentrations of $\mathrm{Cd}$ found in krill in the present study should be the main reason for elevated levels in its predators.

\subsection{Notothenioid fish (Notothenia coriiceps)}

Trace and toxic elements concentrations data in the whole body of notothenioid fish are scarce. Such data are important when tracing biomagnifications in Antarctic trophic chains. The results for Notothenia coriiceps from South Bay (Livingston Island) presented on table 1, were: $\mathrm{Pb}(0.76-1.34 \mathrm{mg} / \mathrm{kg}), \mathrm{Cd}(0.26-0.29 \mathrm{mg} / \mathrm{kg}), \mathrm{Cu}(1.6-1.78 \mathrm{mg} / \mathrm{kg})$, $\mathrm{Zn}(90.8-96.7 \mathrm{mg} / \mathrm{kg})$ and $\mathrm{Mn}(8.75-10.22 \mathrm{mg} / \mathrm{kg})$. Few authors provided data for whole body of notothenioid fish and the available data were expressed in $\mathrm{mg} / \mathrm{kg}$ wet weight, being obtained from other Antarctic regions (e.g. Honda et. al., 1987).

Demersal and pelagic fish and krill show highest element concentrations associated with seafloor sediment, the lowest with seawater particulates and organism tissues.

Livingston Island is the closest to Deception Island, where the whole ecosystem is contaminate with trace elements from local geothermal activity, which is also reflect in the pattern of element contamination in organisms (Deheyn et al., 2005). Accordingly, element concentrations were higher in organisms collected at Deception Island which suggest that toxic and trace elements in this area were incorporated into the marine food web mainly through a dietary route (Deheyn et al., 2005).

\subsection{Crab eater seal (Lobodon carcinophagus)}

Trace and toxic element concentrations in crab eater seal tissues and organs are present in Table 1. The lowest cadmium concentration was found in bones and muscles $(0.1 \pm 0.02 \mathrm{mg} / \mathrm{kg}$ dry weight and below the detection limit), the highest - in kidney $(1.2 \pm 0.14 \mathrm{mg} / \mathrm{kg}$ dry weight), followed by liver $(0.60 \pm 0.14 \mathrm{mg} / \mathrm{kg}$ dry weight). Copper concentrations were found to be from $0.30 \pm 0.09 \mathrm{mg} / \mathrm{kg}$ dry weight in bones to $30.5 \pm 0.24 \mathrm{mg} / \mathrm{kg}$ dry weight in kidneys. The concentration of zinc varied from $52.0 \pm 0.38 \mathrm{mg} / \mathrm{kg}$ dry weight in spleen to $95.0 \pm 0.7 \mathrm{mg} / \mathrm{kg}$ dry weight in liver. As in the case of $\mathrm{Cd}$ the concentrations of $\mathrm{Cu}$ and $\mathrm{Zn}$ were the highest in liver and kidney. Several authors have reviewed levels of metals in seals, however relatively few (Schneider et al., 1985; Steinhagen-Schneider, 1986) have reported the concentration of metals in crabeater seals organs and tissues. They obtained much higher concentration of Cd in liver and kidney in crabeater seal from Weddell Sea. De Moreno et al. (1997) reported cadmium levels in other marine mammals for muscles of southern elephant seals, where they were above the detection limit, whereas in Antarctic fur seals (Malcolm et al., 1994) they were below it.

For Brandsfield Strait there is no available data to compare with, only few data on toxic elements in crabeater seal exist to date. Lead concentrations (Table 1) varied from $0.2 \pm 0.09 \mathrm{mg} / \mathrm{kg}$ dry weight in muscles to $0.96 \pm 0.04 \mathrm{mg} / \mathrm{kg}$ dry weight in kidney. Honda et. al. (1987) determined very low concentrations for Weddell seal in East Antarctica (0.01 $\mathrm{mg} / \mathrm{kg}$ dry weight for liver, kidney, muscle and whole body).

The highest concentrations of manganese and cobalt were found in liver $(13.0 \pm 0.13 \mathrm{mg} / \mathrm{kg}$ dry weight, and $0.50 \pm 0.15$ $\mathrm{mg} / \mathrm{kg}$ dry weight respectively (Table 1 ).

\subsection{Gentoo penguin (Pygoscelis papua ellsworthi)}

The concentrations of lead in Gentoo were low (under detection limit in spleen, liver, feather and muscles). The highest concentration was found in bones $(0.30 \pm 0.14 \mathrm{mg} / \mathrm{kg}$ dry weight) (Table 1). The obtained results were close to the corresponding data reported by Szefer et al. (1994), Honda et al. $(1986,1987)$ and Karasawa and Mishima (1981).

Cadmium concentrations were highest in kidney $(41.2 \pm 0.67 \mathrm{mg} / \mathrm{kg}$ dry weight $)$ and lowest in heart and bones $(0.10 \pm$ $0.02 \mathrm{mg} / \mathrm{kg}$ dry weight). A high level of cadmium in some species seems likely to be due to diet_Lock et al., 1992). Although apparently natural, levels of cadmium in some species greatly exceed those known to have toxic effects in some terrestrial birds. The highest concentrations of copper were found in spleen $(24.70 \pm 0.19 \mathrm{mg} / \mathrm{kg}$ dry weight $)$ and of zinc - in kidney $(232.0 \pm 2.67 \mathrm{mg} / \mathrm{kg}$ dry weight).

In Adelie penguins (Smichowski, 2006) from Potter Cove (King George Island), element concentrations in different organs were observed and the ranges ascertained were as follows: $\mathrm{Cd}<0.07$ in muscle and $3.4 \mathrm{mg} / \mathrm{kg}$ dry weight in kidney; $\mathrm{Cu}-0.6$ in muscle and $18 \mathrm{mg} / \mathrm{kg}$ dry weight in liver; $\mathrm{Pb}-0.1$ in muscle and $2.0 \mathrm{mg} / \mathrm{kg}$ dry weight in liver. The levels of investigated metals in Gentoo at Livingston Island were, in general terms, higher.

\subsection{Brown skua (Catharacta lonnbergi)}

The highest concentrations of lead were detected in feathers $(2.80 \pm 1.13 \mathrm{mg} / \mathrm{kg}$ dry weight $)$ followed by kidney $(1.30 \pm$ $0.52 \mathrm{mg} / \mathrm{kg}$ dry weight) (Table 1). The bioaccumulation of lead in other organs and tissues were around the detection 
limit. The concentration of Cd varied between $0.2 \pm 0.05 \mathrm{mg} / \mathrm{kg}$ dry weight and $70.4 \pm 0.70 \mathrm{mg} / \mathrm{kg}$ dry weight $\mathrm{mg} / \mathrm{kg}$ being the lowest in bone and feathers and the highest in kidney. These levels indicate that brown skua lives on cadmium- rich diet. The results follow the distribution pattern in the closely related South polar skua (Catharacta maccormici) (Schneider at al., 1985) - kidney > liver > muscle. Karasawa and Mishima (1981) obtained very low values in skua muscles from East Antarctica.

Highest copper concentrations were determined in liver $(16.40 \pm 0.13 \mathrm{mg} / \mathrm{kg}$ dry weight $\mathrm{mg} / \mathrm{kg})$, followed by kidney $(14.4 \pm 0.11 \mathrm{mg} / \mathrm{kg}$ dry weight $\mathrm{mg} / \mathrm{kg})$ and muscles $(13.70 \pm 0.11 \mathrm{mg} / \mathrm{kg}$ dry weight). Schneider at al. (1985) obtained similar results for the liver and muscles and very high concentrations in kidney.

Zinc seems to be more evenly distributed in organs and tissues than the other studied elements and varied between 44.0 $\pm 0.43 \mathrm{mg} / \mathrm{kg}$ dry weight in muscles and $203.0 \pm 2.33 \mathrm{mg} / \mathrm{kg}$ dry weight in feather.

Manganese was higher in liver $(15.0 \pm 0.15 \mathrm{mg} / \mathrm{kg}$ dry weight) followed by kidney $(7.1 \pm 0.17 \mathrm{mg} / \mathrm{kg}$ dry weight). Cobalt was evenly distributed and its values were near and under the detection limit.

\section{Trace element presence in the food chain}

Marine organisms accumulate trace metals in tissues up to concentrations several order of magnitude above the environmental levels. Previously the Antarctic environment was considered to be unpolluted and the accumulations of toxic elements were expected to be at the physiologic level. However, it has been shown that the quantities of some trace elements may be higher in many Antarctic species (Honda et al., 1986; Szefer et al., 1994). Due to specific detoxification mechanisms one should expect different degree of biomagnifications of particular trace elements.

Global environmental pollution with $\mathrm{Pb}$ has been shown to influence the ecological system of Antarctica at least to some degree (Sun and Xie, 2001). Anthropogenic sources seems a likely explanation for significant excess of lead and zinc relative to estimated aerosol contributions (Dick, 1991; Bargagli, 2000; Sanchez-Hernandez, 2000) and are generated after long- range transport (Prendez and Carrasco, 2003). Khale and Zauke (2003) mentioned that lead concentrations in Antarctic crustaceans were generally low or below the limits of detection, but elevated levels were measured in some coastal or scavenging species. The results obtained support this and the highest lead concentration was found in brown skua feather.

Cadmium concentrations in all tissues and all the species analyzed were similar, being the highest in predators' kidney followed by liver, spleen and muscle. They fall within the ranges obtained for other marine birds and mammal species (Norheim, 1987; Eisler, 1981). The exact source of metals in the marine ecosystem is unknown, but it is possible that there is a natural rather that anthropogenic origin for cadmium, such as upwelling of cadmium- enriched waters by ocean currents. Along with this, local volcanism, typical for South Shetlands, undoubtedly increases the bioavailability of metals in the Antarctic environment (Honda et al., 1987; Sanchez-Hernandez, 2000). In most Antarctic coastal ecosystems concentrations of $\mathrm{Cd}$ in the waters and biota may be higher than in waters and related species of organisms from polluted coastal areas (Bargagli, 2000). The studied predators depend mainly on Antarctic krill, krill feeding prey and cephalopods, and this is probably the immediate source for the ascertained bioaccumulation of this element in the studied representatives of the Antarctic food chain (Nygard et al., 2001). Comparisons of the Cd levels of the cephalopods showed that those from sub Antarctic area contained very high cadmium concentrations compared to those from lower latitudes. High levels of $\mathrm{Cd}$ in cephalopods from the sub-Antarctic zone correspond closely to the reported high $\mathrm{Cd}$ accumulation in the tissues of top vertebrate predators from the same area. Comparisons showed that top vertebrate predators are often subjected to $\mathrm{Cd}$ doses far in excess of those recommended for humans (Bustamante and al., 1998). The high levels of cadmium in the studied top predators may be explained by its concentration in the main food sources and the "polar cadmium anomaly" (Petri and Zauke, 1993; Bargagli et al., 1996).

Copper and zinc are essential elements. Their concentration is expected to be metabolically regulated in vertebrates, and copper is important for tissue and feathers formation (Underwood, 1977). Therefore, these elements are non-informative for monitoring of anthropogenic impact in Antarctic.

Manganese and cobalt were poorly studied in Antarctic predators. Szefer et al. (1994), Honda et al. (1986), Yamamoto et al. (1996) have published some data on Adelie penguins and krill. Both metals are essential microelements, their toxicity is low and elevated concentration in the environment is inducing by industry. The physiologic levels of these elements in Antarctic fauna are not specified. Thus, further baseline data have to be gathered.

Most of the data in this study fall within the ranges of past investigations undertaken on much larger sample sizes. They enlarge the information about the bioaccumulation in organs and tissue distribution of investigated metals in Antarctic predators. Nova days, all the Antarctic fauna is under strong protection according to the decisions of the CCAMLR 2004 - (Commission for the Conservation of Antarctic Marine Living Resources). Therefore it is necessary to build the future monitoring investigations on noninvasive approaches, including sampling of dead bodies and metabolic nonactive tissues - e.g. molting feathers and skin. The present study supports the view, that current toxicological investigations in Antarctica could be based on noninvasive approaches. 


\section{References}

Bargagli, R., Nelli, L., Ancora, S., \& Focardi, S. (1996). Elevated cadmium accumulation in marine organisms from Terra Nova Bay (Antarctica). Polar Biology, 16, 513 -520.

Bargagli, R. (2000). Trace metals in Antarctica related to climate change and increasing human impact. Review of Environmental Contamination and Toxicology, 166, $129-173$.

Barrera-Oro, E. (2003). Analysis of dietary overlap in Antarctic fish (Notothenioidei) from the South Shetland Islands: no evidence of food competition. Polar Biology, 26, 10, 631-637.

Bustamante, P., Caurant, F., Fowler, S. W., \& Miramand, P. (1998). Cephalopods as a vector for the transfer of cadmium to top marine predators in the north-east Atlantic Ocean. Science of the Total Environment, 220, 71-80.

CCAMLAR. (2004). EMP Standard methods, Hobart, [Online]:http://www.ccamlr.org/pu/e/e pubs/std-meth04.pdf

Deheyn, D. D., Gendreau, Ph., Baldwin, R. J., \& Latz M. I. (2005). Evidence for enhanced bioavailability of trace elements in the marine ecosystem of Deception Island, a volcano in Antarctica. Marine Environmental Research, 60, 1, $1-33$.

Dick, A. L. (1991). Concentration and sources of metals in the Antarctic Peninsula aerosol. Geochim Cosmochim Acta, $55,1827-1836$.

Eisler, R. (1981). Trace metals concentrations in marine organisms. Pergamon, New York, 687.

Holm-Hansen, O. (1985). Nutrient cycles in Antarctic marine ecosystems. In Antarctic Nutrient Cycles and Food Webs, Eds. W.R. Siegfried, P. R. Condy and R. M. Laws, (pp.6-10). Springer, Berlin.

Honda, K., Yamamoto, Y., Hidaka, H., \& Tatsukawa, R. (1986). Heavy metal accumulation in Adelie penguin (Pygoscelis adelie), and their variation with the reproductive processes. Memories of the National Institute for Polar Research (special issue), 40, 443-453.

Honda, K., Yamamoto, Y., \& Tatsukawa, R. (1987). Distribution of heavy metals in Antactic marine ecosystem. Poc. NIPR symp. Polar Biology, 1, 184 - 197.

Kahale, J., \& Zauke, G. P. (2003). Trace metals in Antarctic copepods from the Weddell Sea (Antarctica). Chemosphere, $51,409-417$.

Karasawa, S., \& Mishima, M. (1981). Concentarion of trace metal in tissue of several animals living around Syowa Station, Antarctica. Antarctic Record, 72, 26 -34.

Locarnini, S., \& Presley, B. (1995). Trace element concentrations in Antarctic krill, Euphausia superba. Polar Biology, $15,4,283-288$

Lock, J. W., Thompson, D. R., Furness, R. W., \& Bartle, J. A. (1992). Metal concentrations in seabirds of the New Zealand region. Environmental Pollution, 75, 3, 289-300.

Malcolm, H., Boyd, I., Osborn, S., French, M., \& Freestone, P. (1994). Trace metals in Antarctic fur seal (Arctocephalus gazella) livers from Bird Island, South Georgia. Marine Pollution. Bulletin, 28, 6, 375 -380.

Moreno, J. E. A., Gerpe, M. S., Moreno, V. J., \& Vodopivez, C. (1997). Heavy metals in Antarctic organisms. Polar Biology, 17, 2, $1432-2056$.

Norheim, G. (1987). Levels and Interactions of Heavy Metals in Sea Birds from Svalbard and the Antarctic. Environmental Pollution, 47, 83 - 94.

Nygard, T., Lie, E., Row, N., \& Steinnes, E. (2001). Metal dynamics in an Antarctic food chain. Marine Pollution Bulletin, 42, 7, 598-602.

Petri, G., \& Zauke, G. P. (1993). Trace metals in crustaceans in the Antarctic Ocean. Ambio, 22, 529-536.

Prendez, M., \& Carrasco, A. (2003). Elemental composition of Surface waters in the Antarctic Peninsula and interactions with the environment. Environmental Geoochemistry and Health, 25, 347 - 363.

Sanchez-Hernandez, J. C. (2000). Trace element contamination in Antarctic ecosystems. Review of Environmental Contamination and Toxicology, 166, $83-127$.

Schneider, R., Steinhagen-Schneider, G., \& Drescher, H. (1985). Organochlorines and heavy metals in seals and birds from Weddel Sea. In Antarctic Nutrient Cycles and Food Webs. Eds. W. R. Siegfried, P. R. Condy and R. M. Laws, (pp. 652 - 655). Springer-Verlag, Berlin Heidelberg.

Siniff, D. V. (1991). An overview of the ecology of Antarctic seals. American Zoologist, 31, 1, 143-149.

Smichowski, P., Vodopivez, C., Muñoz-Olivas, R., \& Gutierrez, A. M. (2006). Monitoring trace elements in selected organs of Antarctic penguin (Pygoscelis adeliae) by plasma-based techniques. Microchemical Journal, 82, 1, 1-7. 
Smith, R. C., Baker K., Fraser, W., Hofmann, E., Karl, D., Klink, J., Quetin, L., Precelin, B., Ross, R., Trivelpiece, W., \& Varnet, M. (1995). The Palmer LTER: A Long-Term Ecological Research Program at Palmer Station, Antarctica. Oceanography, 8, 3, 77-86.

Soszka, G., Suplinska, N., Baranski, A., Grzybowska, D., \& Pietruszewski, A. (1981). Trace metals, fluorine and radionuclids in Antarctic krill Euphausia superba Dana. Polish Polar Research, 2, 109 - 117.

Steinhagen-Schneider, G. (1986). Cadmium and copper levels in seals, penguins and skuas from Weddell Sea in 1982/1983. Polar Biology, 5, 139 - 143.

Stoeppler, M., \& Brandt, K. (1979). Comparative studies on trace metals levels in marine biota. II. Trace metals in krill, krill products and fish from the Antarctic Scotia Sea. Zeitschrift Lebensmitel Untersuchung Forschung, 169,95 - 98.

Sun, L., Xie, Z. (2001). Changes in Lead concentrations in Antarctic penguin droppings during the past 3000 years. Environmental Geology, 40, 1205 - 1208.

Szefer, P., Szefer, K., Pempkowiak, J., Skwarnec, B., \& Bojanowski, R. (1994). Distribution and coassociations of selected metals in seals in the Antarctic. Environmental Pollution 83, 341 - 349.

Trivelpiece, W., \& Trivelpiece, S. (1990). Cortship period of Adélie, Gentoo and Chinstrap Penguins. In Davis, L.S., Darby, J.T. (Eds). Penguin biology. (pp. 113-127). Academic Press, San Diego.

Underwood, J. (1977). Trace elements in human and animal nutrition. (4-th ed.) Academic Press, New York

Volkmann, N., Presler, P., \& Trivelpiece, W. (1980). Diet of Pygoscelis penguins at King George Island, Antarctica. Condor, 82, $373-378$.

Walsh, P. (1990). The use of seabirds as monitors of heavy metals in the marine environment. In R., Furness, P.,Rainbow Eds. Heavy Metals in the Marine Environment. CRC Press, Boca Raton.

Yamamoto, Y., Kanesaki, S., Kuramochi, T., Miyazaki, N., Watanaki, Y., \& Naito, Y. (1996). Comparison of trace elements concentrations in tissues of the chick and adult Adelie penguins. Poc. NIPR symp. Polar Biology, 9, $253-262$. 
Table 1. Levels of lead, cadmium, copper, zinc, manganese and cobalt ( $\mathrm{mg} / \mathrm{kg}$ dry weight \pm SD) in different organs and tissues of different Antarctic predators

\begin{tabular}{|c|c|c|c|c|c|c|}
\hline Tissue & $\mathrm{Pb}$ & $\mathrm{Cd}$ & $\mathrm{Cu}$ & $\mathrm{Zn}$ & $\mathrm{Mn}$ & $\mathrm{Co}$ \\
\hline \multicolumn{7}{|c|}{ brown skua (Catharacta lonnbergi) } \\
\hline \multirow{3}{*}{$\begin{array}{l}\text { liver } \\
\text { kidney } \\
\text { bone }\end{array}$} & $<0.4$ & $9.7 \pm 0.36$ & $16.4 \pm 0.13$ & $84.0 \pm 0.62$ & $15.0 \pm 0.15$ & $0.2 \pm 0.06$ \\
\hline & $1.3 \pm 0.52$ & $70.4 \pm 0.70$ & $14.4 \pm 0.11$ & $154.0 \pm 1.77$ & $7.1 \pm 0.17$ & $0.4 \pm 0.12$ \\
\hline & $0.8 \pm 0.36$ & $0.2 \pm 0.05$ & $1.6 \pm 0.20$ & $118.0 \pm 1.36$ & $2.3 \pm 0.21$ & $<0.1$ \\
\hline spleen & $0.8 \pm 0.36$ & $7.5 \pm 0.28$ & $3.1 \pm 0.38$ & $100.0 \pm 0.74$ & $4.4 \pm 0.40$ & $<0.2$ \\
\hline muscle & $<0.5$ & $0.4 \pm 0.09$ & $13.7 \pm 0.11$ & $44.0 \pm 0.43$ & $1.4 \pm 0.13$ & $<0.1$ \\
\hline \multirow{2}{*}{$\begin{array}{l}\text { heart } \\
\text { feathers }\end{array}$} & $<0.7$ & $0.3 \pm 0.07$ & $11.0 \pm 0.08$ & $54.0 \pm 0.40$ & $1.9 \pm 0.17$ & $0.2 \pm 0.06$ \\
\hline & $2.8 \pm 1.13$ & $0.2 \pm 0.5$ & $10.0 \pm 0.56$ & $203.0 \pm 2.33$ & $4.0 \pm 0.36$ & $<0.3$ \\
\hline \multicolumn{7}{|c|}{ gentoo penguin (Pygoscelis papua) } \\
\hline \multirow{3}{*}{$\begin{array}{l}\text { liver } \\
\text { kidney } \\
\text { bone }\end{array}$} & $<0.5$ & $2.32 \pm 0.27$ & $24.7 \pm 0.19$ & $72.0 \pm 0.53$ & $7.1 \pm 0.17$ & $0.20 \pm 0.06$ \\
\hline & $0.1 \pm 0.5$ & $41.2 \pm 0.67$ & $8.1 \pm 0.45$ & $232.0 \pm 2.67$ & $4.9 \pm 0.44$ & $0.2 \pm 0.06$ \\
\hline & $0.3 \pm 0.14$ & $0.1 \pm 0.02$ & $0.9 \pm 0.028$ & $81.0 \pm 0.60$ & $2.5 \pm 0.23$ & $0.1 \pm 0.3$ \\
\hline spleen & $<0.95$ & $3.5 \pm 0.41$ & $24.7 \pm 0.19$ & $232.0 \pm 2.67$ & $6.3 \pm 0.15$ & $0.1 \pm 0.03$ \\
\hline \multirow{3}{*}{$\begin{array}{l}\text { muscle } \\
\text { heart } \\
\text { feathers }\end{array}$} & $<0.6$ & $0.5 \pm 0.12$ & $5.6 \pm 0.31$ & $24.0 \pm 0.24$ & $1.4 \pm 0.13$ & $<0.09$ \\
\hline & $0.2 \pm 0.09$ & $0.10 \pm 0.02$ & $11.3 \pm 0.09$ & $91.5 \pm 0.67$ & $1.0 \pm 0.25$ & $<0.1$ \\
\hline & $<1.9$ & $0.5 \pm 0.12$ & $15.9 \pm 0.12$ & $73.0 \pm 0.54$ & $1.65 \pm 0.15$ & $<0.3$ \\
\hline \multicolumn{7}{|c|}{ crabeater seal (Lobodon carcinophagus) } \\
\hline \multirow{5}{*}{$\begin{array}{l}\text { liver } \\
\text { kidney } \\
\text { bone } \\
\text { spleen } \\
\text { muscle }\end{array}$} & $0.3 \pm 0.14$ & $0.6 \pm 0.14$ & $17.3 \pm 0.13$ & $95.0 \pm 0.7$ & $13.0 \pm 0.13$ & $0.5 \pm 0.15$ \\
\hline & $0.96 \pm 0.04$ & $1.2 \pm 0.14$ & $30.5 \pm 0.24$ & $80.0 \pm 0.59$ & $5.7 \pm 0.14$ & $0.2 \pm 0.06$ \\
\hline & $0.4 \pm 0.18$ & $0.1 \pm 0.02$ & $0.3 \pm 0.09$ & $69.0 \pm 0.51$ & $5.4 \pm 0.13$ & $0.1 \pm 0.03$ \\
\hline & $0.78 \pm 0.09$ & $0.2 \pm 0.05$ & $4.5 \pm 0.55$ & $52.0 \pm 0.38$ & $2.3 \pm 0.21$ & $<0.1$ \\
\hline & $0.2 \pm 0.09$ & $<0.1$ & $4.0 \pm 0.49$ & $75.0 \pm 0.56$ & $1.4 \pm 0.13$ & $<0.1$ \\
\hline \multicolumn{7}{|c|}{ notothenioid fish (Notothenia coriiceps) $\mathrm{n}=3, \min -\max$} \\
\hline & $0.76-1.34$ & $0.26-0.29$ & $1.6-1.78$ & $90.8-96.7$ & $8.75-10.22$ & \\
\hline \multicolumn{7}{|c|}{ krill (Euphausia superba) $\mathrm{n}=19$} \\
\hline whole body & $0.40 \pm 0.18$ & $0.6 \pm 0.14$ & $42.8 \pm 0.33$ & $50.0 \pm 0.49$ & $14.0 \pm 0.14$ & $0.40 \pm 0.12$ \\
\hline
\end{tabular}

